\title{
Vaka Sunumları Demans
}

\section{Sık ve Nadir Görülen Durumlar}

\author{
Editör \\ Serge Gauthier ve Padro Rosa-Neto
}

\section{Çeviri Editörü}

Filiz Koç

Yardımcı Editörler

Ahmet Evlice - Onur Bulut

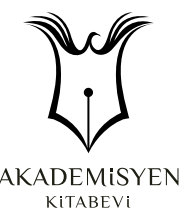


(C) Copyright 2020

Bu kitabın, basım, yayın ve satış hakları Akademisyen Kitabevi A.Ş.'ne aittir. Anılan kuruluşun izni alınmadan kitabın tümü ya da bölümleri mekanik, elektronik, fotokopi, manyetik kağıt ve/ veya başka yöntemlerle çoğaltılamaz, basılamaz, dağıtılamaz. Tablo, şekil ve grafikler izin alınmadan, ticari amaçh kullanılamaz. Bu kitap T.C. Kültür Bakanlı̆ı bandrolü ile satılmaktadır.

$\begin{aligned} \text { ISBN } & \begin{array}{l}\text { Yayın Koordinatörü } \\ \text { Yasin Dilmen }\end{array} \\ \text { K78-605-258-537-5 } & \begin{array}{r}\text { Sayfa ve Kapak Tasarımı } \\ \text { Akademisyen Dizgi Ünitesi }\end{array} \\ \text { Eaka Sunumları Demans } & \text { Yayıncı Sertifika No } \\ \text { Filiz Koç } & 25465 \\ & \text { Baskı ve Cilt } \\ \text { Yardımcı Editörler } & \text { Bizim Dijital } \\ \text { Ahmet Evlice } & \text { Bisac Code } \\ \text { Onur Bulut } & \text { MED056000 } \\ & \text { DOI } \\ & 10.37609 / \text { akya.811 }\end{aligned}$

\section{UYARI}

Bu üründe yer alan bilgiler sadece lisansh tıbbi çalışanlar için kaynak olarak sunulmuştur. Herhangi bir konuda profesyonel tıbbi danışmanlık veya tıbbi tanı amacıyla kullanılmamalıdır. Akademisyen Kitabevi ve alıcı arasında herhangi bir şekilde hekim-hasta, terapist-hasta ve/veya başka bir sağlık sunum hizmeti ilişkisi oluşturmaz. Bu ürün profesyonel tıbbi kararların eşleniği veya yedeği değildir. Akademisyen Kitabevi ve bağlı şirketleri, yazarları, katılımcıları, partnerleri ve sponsorları ürün bilgilerine dayalı olarak yapılan bütün uygulamalardan doğan, insanlarda ve cihazlarda yaralanma ve/veya hasarlardan sorumlu değildir.

İlaçların veya başka kimyasalların reçete edildiği durumlarda, tavsiye edilen dozunu, ilacın uygulanacak süresi, yöntemi ve kontraendikasyonlarını belirlemek için, okuyucuya üretici tarafından her ilaca dair sunulan güncel ürün bilgisini kontrol etmesi tavsiye edilmektedir. Dozun ve hasta için en uygun tedavinin belirlenmesi, tedavi eden hekimin hastaya dair bilgi ve tecrübelerine dayanak oluşturması, hekimin kendi sorumluluğundadır.

Akademisyen Kitabevi, üçüncü bir taraf tarafından yapılan ürüne dair değiş̧iklikler, tekrar paketlemeler ve özelleştirmelerden sorumlu değildir.

\section{GENEL DAĞITIM} Akademisyen Kitabevi A.Ş.

Halk Sokak 5 / A

Yenişehir / Ankara

Tel: 03124311633

siparis@akademisyen.com 


\section{İçindekiler}

Katkıda Bulunanlar vii

Yazarlar $\quad x v$

Önsöz $\quad x v i$

Çeviri Editörün Önsözü $\quad$ xvii

Teşekkür xviii

Demans Tanısına Giriş

Çeviri: Filiz Koç

$\begin{array}{lll}\text { Vaka } 1 & \text { Subjektif kognitif yakınma } & 6\end{array}$

Çeviri: Ahmet Evlice

Vaka 2 Subjektif yakınmaları ve anormal bos bulguları olan erkek hasta 13

Çeviri: Ceren Hangün, Filiz Koç

Vaka 3 Hafif kognitif bozukluk Alzheimer hastalığı olabilir

Çeviri: Ahmet Evlice

Vaka 4 Sözcüklerin kaybı

Çeviri: Fahri Över

Vaka 5 Sağ tarafında his kaybı olan kadın hasta

Çeviri: Ceren Hangül, Filiz Koç

Vaka 6 Yüksek MMDT skoru yanıltıcı olabilir

Çeviri: Serap Bilge

Vaka 7 Hemiparezi sonrası demans

Çeviri: Onur Keskin

Vaka 8 Davranışsal semptomları olan genç erkek vaka

Çeviri: Dilek Işcan

Vaka 9 Vizuel yakınmaları olan kadın hasta

Çeviri: Duygu Güner Özcanyüz 
Vaka 11 İntraserebral kanamaya bağlı progresif afazi

Çeviri: Turgay Demir

Vaka 12 Progresif isimlendirme ve obje tanıma güçlüğü

Çeviri: Turgay Demir

Vaka 13 Güçsüzlük, fasikülasyon ve unutkanlığı olan kadın hasta

Çeviri: Turgay Demir, Filiz Koç

Vaka 14 Progresif konuşma güçlüğü

Çeviri: Turgay Demir

Vaka 15 İlerleyici konuşma bozukluğu ve güçsüzlüğü olan genç erkek hasta

Çeviri: Anıl Tanburoğlu

Vaka 16 Ailesel kişilik değişimi

Çeviri: Ceren Hangül, Filiz Koç

Vaka 17 Sol kolda yakınmaları olan kadın hasta

Çeviri: Dilek İscan

Vaka 18 Yaşlanan beyin: parçalar birbirine uymadığında

Çeviri: Onur Bulut

Vaka 1969 yaşındaki erkekte hiperseksualite

Çeviri: Onur Bulut

Vaka 20 Dalgalı seyirli konfüzyonu olan hasta

Çeviri: Onur Bulut

Vaka 21 Ameliyat sonrası kognitif bozukluk gelişen erkek hasta

Çeviri: Onur Keskin

Vaka 22 Genç erkek demans vakasında tedavide penisilin kullanımı

Çeviri: Filiz Koç

Vaka 23 Genç kadın demans vakasında tedavide tiamin kullanımı

Çeviri: Ceren Hangül, Filiz Koç

Vaka 24 Dizzinessi olan HIV vakası

Çeviri: Serap Bilge, Filiz Koç

Vaka 25 Esrar içen fakat annesi demanstan ölen genç erkek hasta 
Vaka 26 Çocukça davranışları olan üniversite mezunu erkek hasta

Çeviri: Ceren Hangül, Filiz Koç

Vaka 27 Solvent intoksikasyonuna bağlı frontotemporal lober demans:

Yapboza uymayan bir parça

Çeviri: Ceren Hangül, Filiz Koç

Vaka 28 Yürüme güçlüğü yakınması olan erkek hasta

Çeviri: Z. Hale Batur Çağlayan

Vaka 29 İstemsiz hareketleri olan, aile öyküsü bulunmayan genç kadın hasta

Çeviri: Z. Hale Batur Çağlayan

Vaka 30 Sağ gözde görsel halüsiyonları olan yaşlı kadın hasta

Çeviri: Z. Hale Batur Çağlayan

Vaka 31 Yürüme bozukluğu ve okuma güçlüğü olan kadın hasta

Çeviri: Z. Hale Batur Çağlayan

Vaka 32 Okuma ve hesaplama problemleri olan erkek hasta

Çeviri: Necla Keskin

Vaka 33 Yürüme bozukluğu ve idrar inkontinansı olan erkek hasta Çeviri: Necla Keskin

Vaka 34 Unutkanlıktan önce düşme

Çeviri: Necla Keskin

Vaka 35 İçmeyi bırakan adam

Çeviri: Necla Keskin

Vaka 36 Karaciğer hastalığı ve demansı olan kadın

Çeviri: Necla Keskin

Vaka 37 Rekürren "inme" atakları olan genç kadın hasta

Çeviri: Onur Bulut

Vaka 38 Progresif Bilişsel Bozukluk: genç erkek hasta

Çeviri: Onur Bulut

Vaka 39 Lateralize motor semptomları olan genç kadın hasta Çeviri: Elçin Ateş, Onur Bulut 
Unutmak, yaşamın içinde yer alan bir tür ölümdür zaten.

Milan Kundera 


\section{Katkıda Bulunanlar}

\section{Dag Aarsland}

Psychiatric Clinic, Stavanger University Hospital, Stavanger, and AHUS University Hospital, University of Oslo, Oslo, Norway

\section{Adria Arboix}

Cerebrovascular Division, Department of Neurology, Hospital Universitari del Sagrat Cor, Universitat de Barcelona, Barcelona, Spain

\section{Carlos Bazan 111}

Department ofRadiology, School of Medicine, University of Texas Health Science Center at San Antonio and the Audie Murphy Veterans Hospital, San Antonio, TX, USA

\section{James T. Becker}

Departments of Neurology, Psychiatry, and Psychology, Alzheimer's Disease Research Center, University of Pittsburgh School of Medicine, Pittsburgh, PA, USA

\section{Sylvie Belleville}

Institut universitaire de Geriatrie de l'Universite de Montreal, Montreal, QC, Canada

\section{Kevin M. Biglan}

Department of Neurology University of Rochester, Rochester, NY, USA

\section{Sandra E. Black}

Department of Medicine (Neurology), LC Campbell Cognitive Neurology Research Unit, Sunnybrook Health Sciences Centre, University of Toronto, Canada

\section{Mariana Blanco}

Division of Neurology and Rotman Research Institute, Baycrest Centre for Geriatric Care, Toronto, Canada

\section{Remi W. Bouchard}

Departement des Sciences Neurologiques, Centre Hospitalier Affilie Hôpital de l'Enfant-Jesus and Faculte de Medecine, Universite Lava!. Quebec City, Province of Quebec, Canada 


\section{Bruce J. Brew}

Department ofNeurology and Centre for Applied Medical Research, St.

Vincent's Hospital, Sydney, Australia

\section{David J. Burn}

Institute for Ageing and Health, Newcastle University, Newcastle upon Tyne, UK

\section{Leonardo Caixeta}

Hospital das Clinicas, Federal University of Goias, Brazil

\section{Richard Camicioli}

Divisions of Neurology and Neuropathology, University of Alberta Hospital, Edmonton, Canada

\section{Paulo Caramelli}

Federal University of Minas Gerais, Belo Horizonte (MG) and University of Sao Paulo, Brazil

\section{Neil Cashman}

Brain Research Centre, Faculty ofMedicine, University ofBritish Columbia, Canada

\section{Nicholas W. S. Davies}

Department of Neurology \& Centre for Applied Medical Research, St. Vincent's Hospital, Sydney, Australia

\section{Yan Deschaintre}

Hôpital Notre-Dame, Centre Hospitalier de l'Universite de Montreal (CHUM), Montreal, QC, Canada

\section{Rachel S. Doody}

Baylar College of Medicine, Department of Neurology, Alzheimer's Disease and Memory Disorders Center, Houston, TX, USA

\section{Bruno Dubois}

Centre des maladies cognitives et comportementales, Hôpital de la Pitie Salpetriere, Paris, France

\section{Uwe Ehrt}

Psychiatric Clinic, Stavanger University Hospital, Stavanger, Norway

\section{Stephane Epelbaum}

Centre des maladies cognitives et comportementales, Hôpital de la Pitie Salpetriere, Paris, France 


\section{Ryan V. V. Evans}

Department of Neurology University of Rochester, Rochester, NY, USA

\section{Joseph M. Ferrara}

Department of Neurology, University of Louisville, Louisville, KY, USA

\section{Bruno Franchi}

Geriatric Medicine, Royal Adelaide Hospital, Adelaide, Australia

\section{Morris Freedınan}

Division of Neurology, Dept of Medicine, Mt. Sinai Hospital, University Health Network, and University of Toronto, Canada

\section{Anders Gade}

Memory Disorders Research Group, The Neuroscience Centre, Rigshospitalet, Copenhagen University Hospital, Copenhagen, Denmark

\section{Serge Gauthier}

Alzheimer's Disease Research Unit, McGill Center for Studies in Aging, Douglas Mental Health University Institute, McGill University, Quebec, Canada

\section{Marta Grau-Olivares}

Cerebrovascular Division, Department of Neurology, Hospital Universitari del Sagrat Cor, Universitat de Barcelona, Barcelona, Spain

\section{Matthew E. Growdon}

UCSF Memory and Aging Center, San Francisco, CA, USA

\section{Will Guest}

Brain Research Centre, Faculty of Medicine, University of British Columbia, Canada

\section{Marie Christie Guiot}

Montreal Neurological Institute and Hospital, McGill Center for Studies in Aging, Montreal, QC, Canada

\section{Shahul Hameed}

Division of Neurology, Departments of Medicine and Pathology, University of British Columbia, Canada

\section{Mirna Lie Hosogi-Senaha}

Federal University of Minas Gerais, Belo Horizonte (MG) and University of Sao Paulo, Brazil 


\section{Ging-Yuek Robin Hsiung}

Division of Neurology, Departments of Medicine and Pathology, University of British Columbia, Canada

\section{Masamichi Ikawa}

Second Department of Internal Medicine (Neurology), Faculty of Medical Sciences, University of Fukui, Fukui, Japan

\section{Rajive Jassal}

Divisions of Neurology and Neuropathology, University of Alberta Hospital, Edmonton, Canada

\section{Vesna Jelic}

Department of Geriatric Medicine and Department of Neurology, Karolinska University Hospital-Huddinge, Stockholm, Sweden

\section{Peter Johannsen}

Memory Disorders Research Group, The Neuroscience Centre, Rigshospitalet, Copenhagen University Hospital, Copenhagen, Dennıark

\section{Edward S. Johnson}

Divisions of Neurology and Neuropathology, University of Alberta Hospital, Edmonton, Canada

\section{Mary M. Kenan}

Baylar College of Medicine, Department of Neurology, Alzheimer's Disease and Memory Disorders Center, Houston, TX, USA

\section{Bert-Jan Kerklaan}

Department of Neurology and Alzheimer Centre, VU University Medical Centre, Amsterdam, the Netherlands

\section{Benjamin Lam}

L.C. Campbell Cognitive Neurology Research Unit, Department of Medicine (Neurology), Sunnybrook Health Sciences Centre, University ofToronto, Canada

\section{Gabriel C. Leger}

Hôpital Notre-Dame, Centre Hospitalier de l'Universite de Montreal (CHUM), Universite de Montreal, McGill University, Montreal, QC, Canada

\section{Gabriel Leonard}

McGill Center for Studies in Aging, Montreal Neurological Hospital and Institute, Montreal, QC, Canada 


\section{Emilie Lepage}

Institut universitaire de Geriatrie de l'Universite de Montreal, Montreal, QC, Canada

\section{Irene Litvan}

Department of Neurology, University of Louisville, Louisville, KY, USA

\section{Oscar L. Lopez}

Departments of Neurology and Psychiatry, Alzheimer's Disease Research Center, University of Pittsburgh School of Medicine, Pittsburgh, PA, USA

\section{lan R. A. Mackenzie}

Division of Neurology, Departments of Medicine and Pathology, University of British Columbia, Canada

\section{Mario Masellis}

Department ofMedicine (Neurology), LC Campbell Cognitive Neurology Research Unit, Sunnybrook Health Sciences Centre, University of Toronto, Canada

\section{Fodi Massoud}

Hôpital Notre-Dame, Centre Hospitalier de l'Universite de Montreal (CHUM), Montreal, QC, Canada

\section{Paige Moorhouse}

Dalhousie University, Halifax, NS, USA

\section{John C. Morris}

Alzheimer's Disease Research Center, Washington University School of Medicine, St. Louis, Mü, USA

\section{Taim Muayqil}

Divisions of Neurology and Neuropathology, University of Alberta Hospital, Edmonton, Canada

\section{Yannick Nadeau}

Department ofMedicine (Neurology), LC Campbell Cognitive Neurology Research Unit, Sunnybrook Health Sciences Centre, University of Toronto, Canada

\section{Inger Nennesmo}

Department of Pathology, Karolinska University Hospital-Huddinge, Sweden J0rgen E. Nielsen 
Memory Disorders Research Group, The Neuroscience Centre, Rigshospitalet, Copenhagen University Hospital, Copenhagen, Denmark

\section{Ricardo Nitrini}

Behavioral and Cognitive Neurology Unit of the Department of Neurology, University of Sao Paulo School of Medicine, Sao Paulo, Brazil

\section{Sven-Eric Palhagen}

Department ofNeurology, Karolinska University Hospital-Huddinge, Stockholm, Sweden

\section{Robert Perry}

Department of Neuropathology, Newcastle General Hospital, Newcastle upon Tyne, UK

\section{Gerald Pfeffer}

Division of Neurology, University of British Columbia, Canada

\section{Machiel Pleizier}

Department of Neurology and Alzheimer Centre, VU University Medical Centre, Amsterdam, the Netherlands

\section{Steffen Plickert}

St. Katharinen Hospital, Dept. of Neurology, Frechen, Germany

\section{Gil D. Rabinovici}

UCSF Memory and Aging Center, San Francisco, CA, USA

\section{Philippe H. Robert}

Centre Memoire de Ressources et de Recherche, CHU, Universite de Nice Sophia-Antipolis, France

\section{Lothar Resch}

Divisions of Neurology and Neuropathology, University of Alberta Hospital, Edmonton, Canada

\section{Gustavo C. Roman}

Department of Neurology, School ofMedicine, University ofTexas Health Science Center at San Antonio and the Audie Murphy Veterans Hospital, San Antonio, TX, USA

\section{Maxine Ros}

Service de Chirurgie, Hôpital Purpan, Toulouse, France 


\section{Pedro Rosa-Neto}

Alzheimer's Disease Research Unit, McGill Center for Studies in Aging, Verdun, Quebec, Canada

\section{Aiman Sanosi}

Division of Neurology, Department of Pathology, Department of Medicine, University of British Columbia, Canada

\section{Philip Scheltens}

Department of Neurology and Alzheimer Centre, VU University Medical Centre, Amsterdam, the Netherlands

\section{Christian Schmidt}

Georg-August-University Hospital, Dept. of Neurology, German National Reference Center for the Surveillance of Transmissible Spongiform Encephalopathies, Goettingen, Germany

\section{Eric Schmidt}

Service de Neurochirurgie, Hôpital Purpan, Toulouse, France

\section{Jean-Paul Soucy}

Montreal Neurological Hospital and Institute, Montreal, QC, Canada

\section{Jette Stokholm}

Memory Disorders Research Group, The Neuroscience Centre, Rigshospitalet, Copenhagen University Hospital, Copenhagen, Denmark

\section{David Summers}

University of Edinburgh, Western General Hospital, Department of Neuroradiology, Edinburgh, UK

\section{Rawan Tarawneh}

Alzheimer's Disease Research Center, Washington University School of Medicine, WA, USA

\section{Louis Verret}

Neurologist, Departement des Sciences Neurologiques, Centre Hospitalier Affilie Hôpital de l'Enfant-Jesus and Faculte de Medecine, Universite Laval. Quebec City, Province of Quebec, Canada

\section{Huali Wang}

Dementia Care and Research Center, Peking University Institute of Mental Health, Beijing, China 


\section{Bengt Winblad}

Department of Neurology, Karolinska University Hospital-Huddinge and Karolinska Institutet, Alzheimer Disease Research Centre, Karolinska University Hospital, Stockholm, Sweden

\section{Makoto Yoneda}

Second Department of Internal Medicine (Neurology), Faculty of Medical Sciences, University of Fukui, Fukui, Japan

\section{Xin Yu}

Dementia Care and Research Center, Peking University Institute of Mental Health, Beijing, China

\section{Inga Zerr}

Georg-August -University Hospital, Dept. of Neurology, German National Reference Center for the Surveillance of Transmissible Spongiform Encephalopathie s, Goettingen, Germany 


\section{Yazarlar}

Filiz Koç

Çukurova Üniversitesi Tıp Fakültesi

Ahmet Evlice

Çukurova Üniversitesi Tıp Fakültesi

Onur Bulut

Dokuz Eylül Üniversitesi Tıp Fakültesi

\section{Ceren Hangül}

Akdeniz Üniversitesi Tıp Fakültesi

Serap Bilge

Çukurova Üniversitesi Tıp Fakültesi

Duygu Güner Özcanyüz

Çukurova Üniversitesi Tıp Fakültesi

\section{Fahri Över}

Adana Dr. Ekrem Tok Ruh Ve Sinir Hastalıkları Hastanesi

Dilek İşcan

Aksaray Üniversitesi Eğitim Ve Araştırma Hastanesi

\section{Elçin Ateș}

Çukurova Üniversitesi Tıp Fakültesi

\section{Anıl Tanburoğlu}

Başkent Üniversitesi Adana Dr. Turgut Noyan Araştırma ve Uygulama Merkezi

\section{Onur Keskin}

Başkent Üniversitesi Adana Dr. Turgut Noyan Araştırma ve Uygulama Merkezi

\section{Necla Keskin}

Sağlık Bilimleri Üniversitesi Van Eğitim ve Araştırma Hastanesi

\section{Z. Hale Batur Çağlayan}

Gazi Üniversitesi Tıp Fakültesi 


\section{Önsöz}

Demans Vaka Çalışmalarının arkasındaki ana fikir, çeşitli hastalıkların klinik sunumlarının spektrumunda yer alan ve ortak payda olan demansa genel bir bakış sağlamaktır. Hızla gelişen klinik nörolojinin bir alanı olan demansın ayırıcı tanısı ve klinik değerlendirmesi giderek daha sofistike ve karmaşık hale geliyor. Bu vaka çalışmalarının tıp öğrencilerine, aile hekimlerine ve nörologlara, hastalığı anlama ve yönetme konusunda yararlı olacağını umuyoruz.

Serge Gauthier ve Pedro Rosa Neto 


\section{Çeviri Editörün Önsözü}

Dünya Sağlık Örgütü verilerine göre, dünyada yaklaşık 50 milyon insan demans ile mücadele etmekte ve bu sayıya her üç saniyede bir yeni vaka eklenmektedir. Bu rakamın 2050 yılında üçe katlanacağı tahmin edilmektedir. Demansla ilgili 2017-2025 küresel eylem planı, hastalı̆̆ın toplumlar ve ülkeler üzerindeki sosyal ve ekonomik yükünü azaltmayı, hasta ve bakım verenlerin günlük yaşamlarını iyileştirmeyi amaçlamaktadır. Ayrıca inaktivite, sigara içme, beslenme bozukluğu, alkol kötüye kullanımı, obezite, hipertansiyon, diyabet, dislipidemi, depresyon, işitme kaybı, yetersiz sosyal aktivite, etkilenmiş kognitif rezerv, sosyal aktivite eksikliği, sağlısız kilo alımı, hipertansiyon, diyabet, dislipidemi (sağlıksız kolesterol düzeyleri), depresyon ve işitme kaybı gibi değiştirilebilir on iki demans risk faktörlerinin erken tanı ve tedavisi konusunda farkındalık oluşturmaya çalışmaktadır.

Bu kitapta bilişsel fonksiyonlarda etkilenme ile kliniğe kabul edilen, farklı yaş aralığına sahip, kognitif etkilenmeye yol açan hastalıkların tipik olduğu kadar atipik özelliklerini barındıran farklı vaka sunumları yer almaktadır.

Kitabın hazırlık aşamasından basım aşamasına gelinceye kadar ki süreçte katkı sunan bölüm yazarlarına sonsuz teşekkür ediyoruz. Kitapta yer alan her bir vakanın okuyucuya demans tanı ve yönetimi konusunda katkı sunması dileklerimizle...

Prof. Dr. Filiz Koç 


\section{Teşekkür}

Vaka yorumları ve klinik görüşleri için katkıda bulunan ekibe teşekkür ederiz. Onların gayretli çalışmaları bu kitabın basımını zevkli bir iş haline getirdi. Ayrıca Dorothée Schoemakerıa (MCSA), Mary Sanders, Nisha Doshi ve Caroline Brown`a (Cambridge University Press) mükemmel editoryal yardımlarından dolayı teşekkür ederiz. 


\section{KAYNAKÇA}

Ali ZS, Van Der Voora JP, Powers JM (2007). A comparative morphologic analysis of adult onset leukodystrophy with neuroaxonal spheroids and pigmented glia-a role for oxidative damage. Journal of Neuropathology and Experimental Neurology, 66(7), 660-72. doi:10.1097/ nen.ObOI3e3180986247

Baba Y, Ghetli B, Baker MC, Litti RJ, Hutton ML, Yamaguchi K, Bird T, Lin W, DeLucia MW, Dickson DW, Wszolek ZK (2006). Hereditary diffuse Ieukoencephalopathy with spheroids: Clinical, pathologic and genetic studies ot a new kindred. Acta Neuropathology, 111(4). 300-11. doi: 10.1007/s00401-006-0046-z

Chui HC, Victoroff JI, Margolin D, Jagust W, Shankle R, Katzman R (1992). Criteria for the diagnosis of ischemic vasuilar dementia proposed by the state of california alzheimer's disease diagnostic and treatment centers. Neurology, 42(3 Pt 1), 473-80.

Costcllo DJ, Eichler AF, Eichler FS (2009). Leukodystrophies: Classification, diagnosis, and treatment. The Neurologist, 15(6), 319-28. doi:10.1097/NRL.0b013e3181b287c8

Doody RS, Pavlik V, Massman P, Rountree S, Darby E, Chan W (2010). Predicting progression of alzheimer's disease. Alzheimer's Research \& Therapy, 2(1), 2. doi:10.1186/alzrt25

Freeman SH, Hyman BT, Sims KB, Hedley-Whyte ET, Vossough A, Frosch MP, Schmahmann JD (2009). Adult onset leukodystrophy with neuroaxonal spheroids: Clinical, neuroimaging and neuropathology observations. Brain Pathology (Zurich, Switzerland), 19(1), 39-17. doi:10.11111/j.1750-3639.2008.00163.x

Lopez OL, Wisniewski S, Hamilton RL, Becker JT, Kaufer DI, DeKosky ST (2000). Predictors of progression in patients with AD and lewy bodies. Neurology, 54(9), 1774-9.

O'Sullivan M, Jarosz JM, Martin RJ, Deasy N, Powell JE, Marfan HS (2001). MRI hyperintensities of the temporal lobe and external capsule in patients with CADASIL. Neurology, 56(5). 628-34.

Petersen RC, Morris JC (2005). Mild cognitive impairment as a clinical entity and treatment target. Archives of Neurology, 62(7), 1160-3; discussion 1167. doi:10.1001/ archneur.62.7.1160

Portet F, Scarmeas N, Cosentino S, Helzner EP, Stern Y (2009). Extrapyramidal signs before and after diagnosis of incident alzheimer disease in a prospective population study. Archives of Neurology, 66(9), 1120-6. doi:10.1001/archneurol.2009.196

Ridha B, Josephs KA (2006). Young-onset dementia: A practical approach to diagnosis. The Neurologist, 12(1), 2-13. doi:10.1097/01.nrl.0000186798.86255.69

Rudzinski LA, Fletcher RM, Dickson DW, Crook R, Hutton ML, Adamson J, GraffRadford NR (2008). Early onset familial alzheimer disease with spastic paraparesis, dysarthria, and seizures and N135S mutation in PSEN1. Alzheimer Disease and Associated Disorders, 22(3), 299-307. doi:10.1097/WAD.0b013e3181732399

Sampson EL, Warren JD, Rossor MN (2004). Young onset dementia. Postgraduate Medical Journal, 80(941), 125-39.

Scarmeas N, Honig LS, Choi H, Cantero J, Brandt J, Blacker D, Albert M, Amatniek JC, Marder K, Bell K, Hauser WA, Stern Y (2009). Seizures in alzheimer disease: Who, when, and how common? Archives of Neurology, 66(8), 992-7. doi:10.1001/ archneurol.2009.130

Schott JM, Fox NC, Rossor MN (2002). Genetics of the dementias. Journal of Neurology, Neurosurgery, and Psychiatry, 73 Suppl 2, 1127-31. 
Staekenborg SS, van der Flier WM, van Straaten EC, Lane R, Barkhof F, Scheltens P (2008). Neurological signs in relation to type of cerebrovascular disease in vascular dementia. Stroke; a Journal of Cerebral Circulation, 39(2), 317-22. doi:10.1161/ STROKEAHA.107.493353

Tournier-Lasserve E, Iba-Zizen MT, Romero N, Bousser MG (1991). Autosomal dominant syndrome with strokelike episodes and leukoencephalopathy. Stroke; a Journal of Cerebral Circulation, 22(10), 1297-302.

Whiteman ML, Post MJ, Berger JR, Tate LG, Bell MD, Limonte LP (1993). Progressive multifocal leukoencephalopathy in 47 HIV-seropositive patients: Neuroimaging with clinical and pathologic correlation. Radiology, 187(1), 233-40.

Wider C, Van Gerpen JA, DeArmond S, Shuster EA, Dickson DW, Wszolek ZK (2009). Leukoencephalopathy with spheroids (HDLS) and pigmentary leukodystrophy (POLD): A single entity? Neurology, 72(22), 1953-59. doi:10.1212/ WNL.0b013e3181a826c0 